\title{
Heavy Metals Distribution and Their Correlation with Clay Size Fraction in Stream Sediments of the Lesser Zab River at Northeastern Iraq
}

\author{
Abbas Rasheed Ali, Mohammad Jamil Ali Talabani* \\ Department of Applied Geology, Faculty of Science, University of Kirkuk, Kirkuk, Iraq \\ Email: *talabanimohammad@gmail.com
}

How to cite this paper: Ali, A.R. and Talabani, M.J.A. (2018) Heavy Metals Distribution and Their Correlation with Clay Size Fraction in Stream Sediments of the Lesser Zab River at Northeastern Iraq. Journal of Geoscience and Environment Protection, 6, 89-106.

https://doi.org/10.4236/gep.2018.64006

Received: January 20, 2018

Accepted: March 30, 2018

Published: April 2, 2018

Copyright $\odot 2018$ by authors and Scientific Research Publishing Inc. This work is licensed under the Creative Commons Attribution International License (CC BY 4.0).

http://creativecommons.org/licenses/by/4.0/

\begin{abstract}
Heavy metals (i.e. $\mathrm{Cr}, \mathrm{Co}, \mathrm{Ni}, \mathrm{Cu}, \mathrm{Zn}, \mathrm{Rb}, \mathrm{Sr}, \mathrm{Ba}, \mathrm{Pb}, \mathrm{V}$ and $\mathrm{Ga}$ ) distribution and their correlation with clay fraction were investigated. Fifteen samples of stream sediments were collected from the Lesser Zab River (LZR), which represent one of three major tributaries of the Tigris River at north-eastern Iraq. Grain size distributions and textural composition indicate that these sediments are mainly characterized as clayey silt and silty sand. This indicates that the fluctuation in the relative variation of the grain size distribution in the studied sediments is due local contrast in the hydrological conditions, such as stream speed, energy of transportation and geological, geomorphological and climatic characterizations that influenced sediments properties. On the other hand, clay mineral assemblages consist of palygorskite, kaolinite, illite, chlorite and smectite, which in turn reveals that these sediments were derived from rocks of similar mineralogical and chemical composition as it is coincided with other published works. The clay mineral assemblages demonstrate that major phase transformations were not observed except for the palygorskite formation from smectite, since the minerals pair exhibit good negative correlation $(-0.598)$ within the Lesser Zab River (LZR) sediments. To determine interrelation between the heavy metals and the clay fractions in the studied samples, correlation coefficients and factor analysis were performed. Heavy metals provide significant positive correlation with themselves and with $\mathrm{Al}_{2} \mathrm{O}_{3}, \mathrm{Fe}_{2} \mathrm{O}_{3}$ and $\mathrm{MnO}$. In addition, the results of factor analysis extracted two major factors; the first factor loading with the highest percent of variation (60\%) from the major $\left(\mathrm{Fe}_{2} \mathrm{O}_{3}, \mathrm{Al}_{2} \mathrm{O}_{3}\right.$ and $\mathrm{MnO}$ in weight \%), heavy metals and clay fraction. While the second factor with the (14\%) of variance includes $\mathrm{Cr}$ and silt fraction, which indicate the affinity of the heavy metals
\end{abstract}


being adsorbed onto solid phase like clay particles. These observations suggest that a common mechanism regulates the heavy metal abundance, and that their concentrations are significantly controlled by fine clay fractions, clay mineral abundance and ferro manganese oxides-hydroxides.

\section{Keywords}

Heavy Metal, Lesser Zab River, Northeastern Iraq, Clay Mineral, Size Fraction

\section{Introduction}

Fluvial sediments are sourced from the exposed rocks, among these, the crystalline rocks, which are influenced by streams under surface conditions. Other fluvial sediments origins are from soils which pass the mineralogical composition from the source rock and/or alter them, and new mineral faces could form [1]. Sediments include different grain sizes (i.e. coarse sandstone to colloidal grains). Thus, studying resent sediments offer insight on the physiochemical and environmental regimes in shallow marine and fluvial conditions which are influenced greatly by the changes of earth and human activities [2] [3], and therefore, sediments are used, usually, as pollution monitor in different aquatic regimes. On the other hand, colloidal grains are greatly influenced by various parameters and thus hardly to provide accurate analysis results. While fine grain sediments are less influenced and therefore used frequently as chemical and biochemical pollution indicators [4].

Moreover, fluvial sediments, in comparison, represent the main heavy metals settling agent in water systems and those heavy metals are not washed out from the system; instead it could be induced within the water and sediments storage by various biological and chemical processes [5] [6] [7]. Thereafter, heavy metals, of various origins, main source of enrichments in water systems are through rock and soil erosion in fine grain sediments [8] [5] [9] [10].

Additionally, tiny size sediments (i.e. clay size) are the main size fraction used by researchers to determine heavy metals concentrations which are related in part to their mobility [11] [12]. Furthermore, heavy metals are adsorbed on negative charge surfaces such as clay minerals, organic materials and other oxides, within insoluble organic and inorganic bond form, in the aquatic regimes by several human activities [5] [12]. This study aims to identify clay minerals assemblages and their relationship with the heavy metals distribution and origins within the Lesser Zab river (LZR) sediments.

\section{Geological Setting}

The regional geology of northern Iraq consists of the Zagros Mountains Range with an NW-SE structural trend in the north-eastern part, and Taurus mountain Range with an E-W structural trend in the north and northwestern parts. The 
structural framework of Iraq was divided by [13] into Thrust Zone, Folded Zone and Unfolded Zone (Figure 1).

The LZR and its tributaries traverse the Zagros Suture and the Unstable Shelf tectonic zones of northeastern Iraq. The Zagros Suture Zone which is shared between Iran and Iraq consists dominantly of igneous and metamorphic rocks belonging to Shalair, Penjween-Walash and Qulqula-Khwaqurk Zones [14]. The unstable shelf is dominated by sedimentary rock formations which are parts of three tectonic zones; Imbricated, high folded and foothill zones. It is important to know the general lithological characteristic of the rock units and formations which form the bed rock of the LZR and its tributaries because of these bed rocks make the source of water and recent sediments.

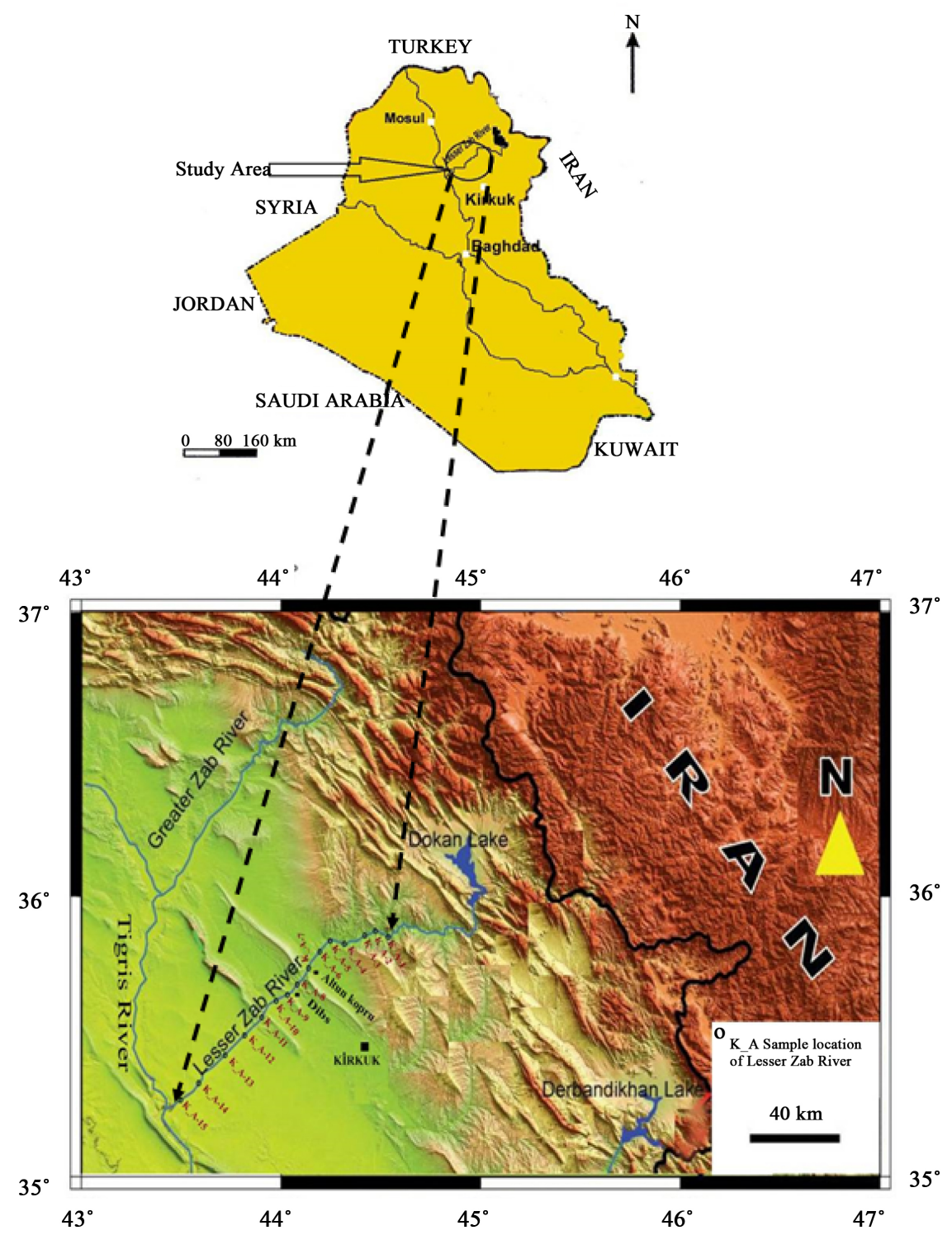

Figure 1. Location map showing sediment sampling locations in the LZR (after Ali, 2012). 
The LZR traverses many tectonic and rock units belonging to the Unstable shelf which were divided by [14] in to four divisions: Zagros suture zones including (Penjween-Walash zone), imbricated zone (Balambo-Tanjero zone), High folded zone and Foot hill zone (Hamrin-Makhul sub zone). Tectonically, the study area extends from highly Folded Zone of the Foreland Basin into the foreland and related basins, as well as the platform region of the Arabian Plate (Figure 2). According to [15] the folded zone contains three tectonic zones which are, from west to east: the Mesopotamian zone (Quaternary molasses and buried structures), the Foothill zone (Neogene molasses and long anticlinal structures separated by broad synclines), and High Folded zone (Paleogene molasses and harmonic folded structures). These longitudinal tectonic zones are segmented into blocks bounded by ENE-WSW (shifting to NE-SW) transverse faults with both vertical and horizontal displacement. The transverse blocks have been active, at least, since the late Cretaceous and greatly influenced the sedimentary facies of the Cretaceous and Tertiary sequences [16]. Structurally, the studied area (Lesser Zab River) lies in the Foothill and high Folded zones of the platform foreland of Iraq as shown in Figure 2 [17].

The LZR is situated between $360^{\circ} 00^{\prime} 23.67^{\prime \prime}$ - 350 41'14.9" North and $450^{\circ} 14^{\prime} 29.75^{\prime \prime}-440^{\circ} 03^{\prime} 35.4^{\prime \prime}$ East. The elevation ranges between 230 and $631 \mathrm{~m}$ above sea level. The LZR travels $400 \mathrm{~km}$ until its junction with the Tigris River at $35 \mathrm{~km}$ southwest Sharqat city and its catchment covers an area of 22,250 $\mathrm{km}^{2}$ (Figure 3) [18]. The river in the study area passes through many villages, towns and agricultural lands where possible man-made pollution sources could affect its water quality, in addition to the natural pollution causes such as spring waters, erosion and weathering of outcrops, etc. [10]. River collects its water from

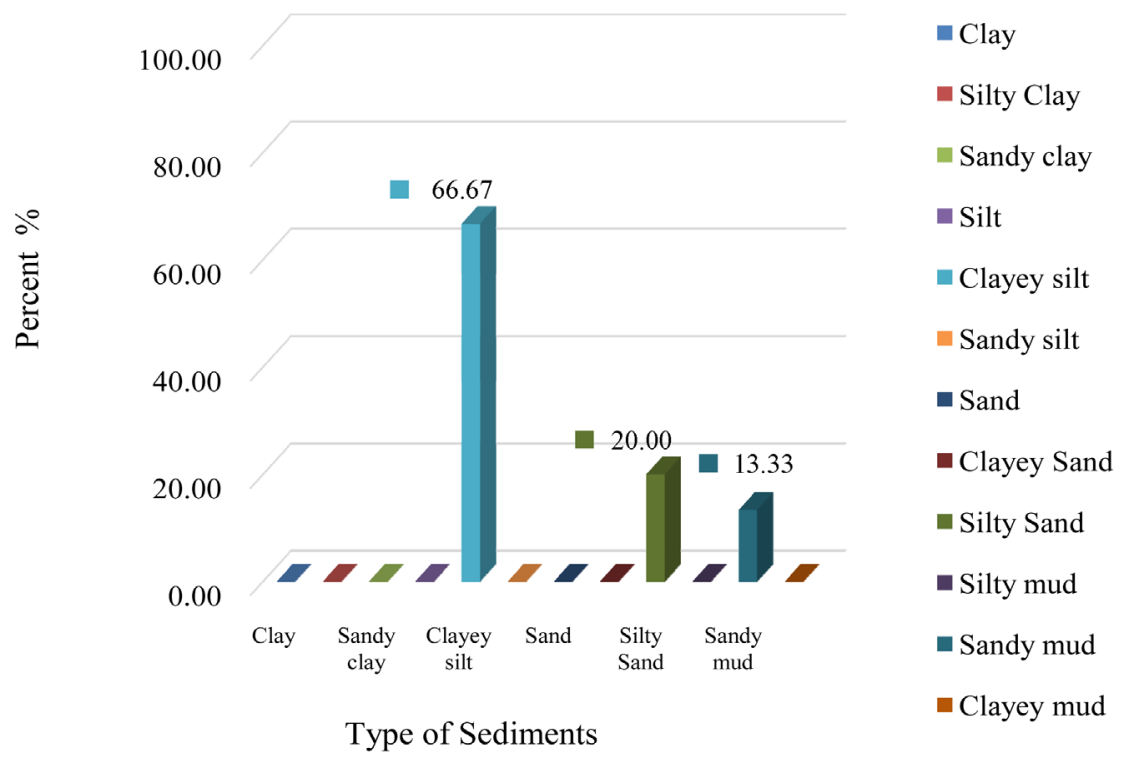

Figure 2. The bar shape illustrates the relationship between type of sediment and the percentages for each type. 


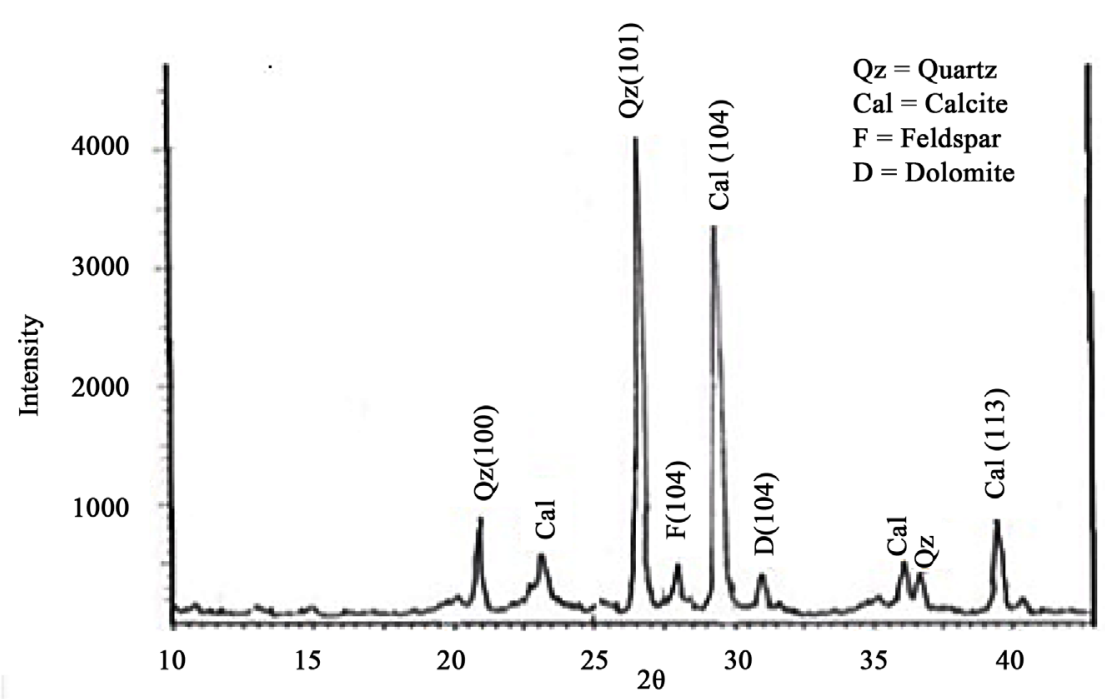

Figure 3. X-ray Diffraction pattern showing the main detected minerals of studied bulk sample.

the northeast drainage area. Lesser river is sourced from the Zagros suture zone are in N-NE Iraq and then merge with other rivers in Tigris River to the SW of the area.

\section{Material and Methods}

Fifteen recent sediment samples were collected from the lesser Zab Main stream (Figure 3) located in the north-eastern of Iraq during April 2009. About 2 - $4 \mathrm{~kg}$ of sediments were collected manually from the main stream in contact with running water using a metal bucket of the dimensions $26 \times 8 \times 3 \mathrm{~cm}^{3}$. Sampling was performed at distance from the river banks to avoid possible contamination from the bank material. Details of the analysis techniques are given in [19] [20].

The samples were sun-dried and then ground into fine powder in an agate mortar. The samples were sieved to pass through of $200 \mu \mathrm{m}$, and then pressed into thick pellets of $32 \mathrm{~mm}$ diameter using wax as blinder. USGS standards, GEOL, GBW 7109 and GBW-7309 sediment equally pressed into pellets in an equivalent manner as the samples, and these used for quality assurance [19] [20]. Multi-element concentration was determined by using polarized energy dispersive XRF. The PEDXRF analysis was carried out at the Earth Sciences Research and Application Center of Ankara University, TURKEY using Spectro XLAB 2000 PEDXRF spectrometer and following [21].

Grain size analysis is carried out to separate sand from the silt and clay using sieve $(0.063 \mathrm{~mm}, 230$ meshes) by wet sieving. The silt and clay fractions downward from (230 mesh) sieve were separated using sedimentation tube method according to [22] [23]. The statistical parameters of the grains were calculated using the equations proposed by [24].

Mineralogical characteristics of the samples were determined by using X-ray 
diffraction analysis, type $\mathrm{P}$ analytical Xpert PRO MPD with Ni-filtered and $\mathrm{CuK}$ $\alpha$ radiation, for diagnosis and assessment of mineral components as well as identifying the type of clay minerals in the isolated clayey size $(<2 \mu \mathrm{m})$. Both randomly oriented powder and slide samples were prepared following the procedure described by [23] [25]. They were scanned over the range from $5^{\circ}$ to $40^{\circ} 2 \theta$ at a scanning speed $2^{\circ} 2 \theta / \mathrm{min}$. The oriented slides were analyzed in various stages (non-treated, treated by Glycol ethylene at $60^{\circ} \mathrm{C} / 2 \mathrm{hr}$. to distinguish the expandable mineral phases, the slides were heated at $550^{\circ} \mathrm{C} / 2 \mathrm{hr}$. for chlorite detection). All minerals basal reflection peaks were identified according to ASTM cards [26]. The semi quantitative determination of the relative amounts of major clay minerals was calculated by using analytical Xpert High Score software depending up on specific reflections and intensity factors.

\section{Results and Discussion}

\subsection{Sediment Grain Size and Mineralogical Analysis}

The results of the grain size analysis and textural composition of the studied sediment samples are given in Table 1 and Figure 2, which provide the percentages of the sediments components of sand, silt and clay. The results indicate clearly decrease in the sand percentage from $80 \%$ to $1 \%$ with an average of $22.7 \%$, while the silt portion was high in all sites (i.e. $12 \%-87 \%$ with an average

Table 1. Results of the grain size analysis and the common texture of the LZR sediments following Carver, 1971.

\begin{tabular}{ccccc}
\hline Sample No. & Sand Fraction $\%$ & Silt Fraction $\%$ & Clay Fraction $\%$ & Texture \\
\hline K_A-1 & 42 & 42 & 16 & Sandy mud \\
K_A-2 & 80 & 12 & 8 & Silty Sand \\
K_A-3 & 64 & 31 & 5 & Silty Sand \\
K_A-4 & 8 & 63 & 29 & Clayey silt \\
K_A-5 & 47 & 35 & 18 & Clayey silt \\
K_A-6 & 40 & 34 & 26 & Silty Sand \\
K_A-7 & 5 & 80 & 15 & Clayey silt \\
K_A-8 & 1 & 87 & 12 & Clayey silt \\
K_A-9 & 4 & 79 & 17 & Clayey silt \\
K_A-10 & 2 & 56 & 42 & Clayey silt \\
K_A-11 & 3 & 57 & 40 & Clayey silt \\
K_A-12 & 2 & 58 & 40 & Clayey silt \\
K_A-13 & 32 & 32 & 36 & Sandy mud \\
K_A-14 & 2 & 50 & 48 & Clayey silt \\
K_A-15 & 8 & 61.8 & 31 & Clayey silt \\
Average & 22.7 & & & \\
\hline & & 5.5 & \\
\hline
\end{tabular}


of 51.8\%). The quantity of clays was relatively less than silt, and ranges between $5 \%$ to $48 \%$ (25.5\% in average), and its percentage declines inversely to the silt portions. According to [27] classification, most of the studied recent LZR sediments can be classified as clayey silt and silty sand types which compose of $66.67 \%$ and $20.0 \%$ respectively of the studied samples (Figure 2). This indicates that the fluctuation in the relative variation of the grain size distribution within the studied sediments because of the local contrast in the hydrological conditions, like stream speed, energy of transportation and geological, geomorphological and climatic natures that influenced sediments properties [28].

Moreover, XRD patterns of the oriented and non-oriented slides which are obtained under different measurement conditions, as shown in Figure 3 and Figure 4, reveals the existence of clay and non-clay minerals contents. Non-clay minerals are represented by quartz that appeared at the basal reflections 3.34, 4.26, 2.46, $2.28 \AA$, calcite $3.04 \AA$, dolomite $2.89 \AA$ and feldspar $3.2 \AA$; whereas clay minerals includes; kaolinite that appeared at the basal reflections 7.16, 3.57 $\AA$, illite 10, $5 \AA$, chlorite 14, 7.1, $3.53 \AA$, palygorskite 10.5, $6.5 \AA$ and smectite 13 $15 \AA$ (Figure 4).

Clay mineral assemblages consist mainly of palygorskite $(32.94 \%-40.44 \%)$ with an average of $(37.20 \%)$, kaolinite $(22.53 \%-26.14 \%)$ and illite $(21.92 \%$ $26.17 \%)$ are in lesser abundance with averages of (24.55\% and $24.11 \%)$, respectively. Whereas chlorite $(14.05 \%-23.74 \%)$ and smectite $(11.89 \%-16.57 \%)$ are frequently presented in small quantities in all studied sediment samples with averages of $19.07 \%$ and $14.15 \%$ respectively (Table 2 ). The recorded clay minerals in the recent LZR sediments are coincided with previous works within older rock units and as suggested by [18] [29]. This suggests that these sediments are inherited from other source rocks exposed in the catchment drainage basin of LZR. Thus, major transformation was not observed in these sediments except for new formation of palygorskite from the transformation layer of smectite, since the minerals pair exhibit good negative correlation $(-0.598)$ in the LZR sediments.

\subsection{Heavy Metal Concentrations in Clay Fractions}

The concentrations of heavy metals (i.e. $\mathrm{Co}, \mathrm{Cr}, \mathrm{Cu}, \mathrm{Ni}, \mathrm{Ba}, \mathrm{Pb}, \mathrm{Rb}, \mathrm{Zn}, \mathrm{V}$ and $\mathrm{Ga})$ and major elements $\left(\mathrm{Al}_{2} \mathrm{O}_{3}, \mathrm{Fe}_{2} \mathrm{O}_{3}\right.$ and $\left.\mathrm{MnO}\right)$ within clay fraction $(<2 \mu \mathrm{m})$ sediments and their portioning in the Lesser Zab stream are provided in (Table 3 ) and (Figure 5). Statistical parameters of the data (arithmetic mean, maximum and minimum value, standard deviation and coefficient of variation) were calculated to observe general variability in the LZR sediment chemistry (Table 3). The concentrations of trace elements generally vary by $5 \%$ to $27 \%$ for the LZR. Coefficient of variation (C.V.) is maximum (20\% - 27\%) for Co, $\mathrm{Rb}$ and $\mathrm{Zn}$, $(16 \%-20 \%)$ for $\mathrm{Pb}$ and $\mathrm{Cu},(10 \%-15 \%)$ for $\mathrm{Cr}$ and $\mathrm{Ga}$, and is within $<10 \%$ for other elements (Table 3 ).

The average contents of $\mathrm{Al}_{2} \mathrm{O}_{3}, \mathrm{Fe}_{2} \mathrm{O}_{3}$ and $\mathrm{MnO}$ are about 9.98\%, 6.27\% and 


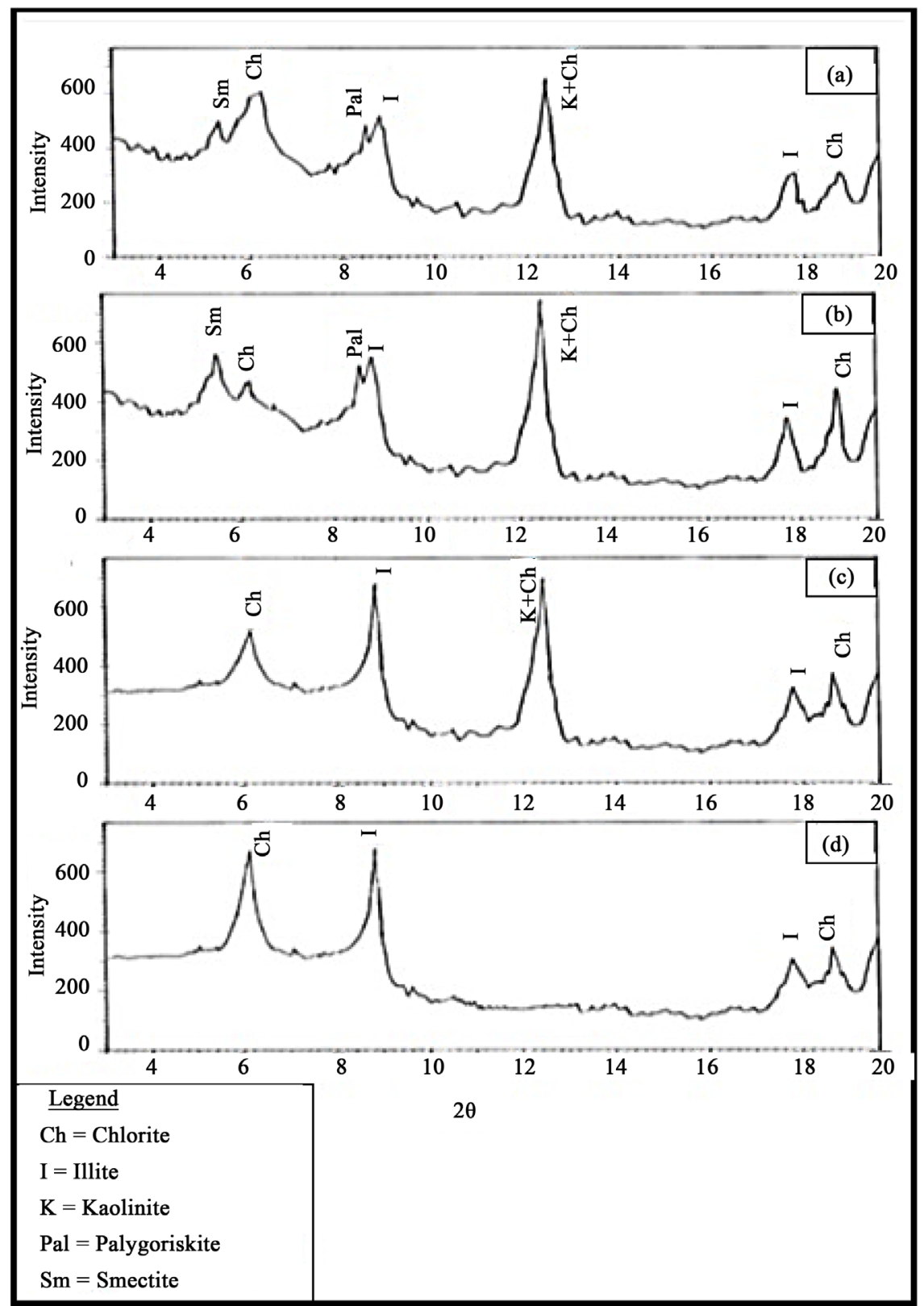

Figure 4. X-ray Diffraction pattern from clay minerals of studied clay fraction sample. (A) Normal Sample (without treatments); (b) Sample; (c) Heated to $350^{\circ} \mathrm{C}$; (d) Heated to $550^{\circ} \mathrm{C}$.

$0.086 \%$ respectively; the source of these oxides is mostly clay minerals as well as contributions from silica-rich minerals such as quartz and feldspar. [10]-[18] illustrated that the concentrations of $\mathrm{Fe}_{2} \mathrm{O}_{3}$ and $\mathrm{MnO}$ of the LZR sediments are significantly controlled by ferro manganese oxides-hydroxides, clay and carbonate minerals abundances that are progressively diluted by quartz content.

In addition to the major elements described above, ten trace elements $(\mathrm{Co}, \mathrm{Cr}$, $\mathrm{Cu}, \mathrm{Ni}, \mathrm{Ba}, \mathrm{Pb}, \mathrm{Rb}, \mathrm{Zn}, \mathrm{V}$ and $\mathrm{Ga}$ ) analyzed in the in the clay fraction samples collected from LZR sediments (Table 4). The relationship between major and 
Table 2. Estimation of clay mineral constituents of LZR sediment samples.

\begin{tabular}{|c|c|c|c|c|c|}
\hline \multirow{2}{*}{ Sample Number } & \multicolumn{5}{|c|}{ Clay Mineral (Clay Fraction) \% } \\
\hline & $\mathrm{Ch}$ & $\mathrm{Sm}$ & I & $\mathrm{K}$ & $\mathrm{P}$ \\
\hline K_A-1 & 17.00 & 12.86 & 24.97 & 24.56 & 37.61 \\
\hline K_A-2 & 20.81 & 15.21 & 26.17 & 25.68 & 32.94 \\
\hline K_A-3 & 16.48 & 14.71 & 22.30 & 25.97 & 37.02 \\
\hline K_A-4 & 16.97 & 11.89 & 21.92 & 25.76 & 40.44 \\
\hline K_A-5 & 14.05 & 15.68 & 25.61 & 23.97 & 34.74 \\
\hline K_A-6 & 22.85 & 15.82 & 23.34 & 23.88 & 36.96 \\
\hline K_A-7 & 17.41 & 16.54 & 22.26 & 25.63 & 35.58 \\
\hline K_A-8 & 16.40 & 13.10 & 23.11 & 24.04 & 39.75 \\
\hline K_A-9 & 19.77 & 13.47 & 23.85 & 24.08 & 38.60 \\
\hline K_A-10 & 17.86 & 14.62 & 25.78 & 22.99 & 36.61 \\
\hline K_A-11 & 19.10 & 13.62 & 22.23 & 25.54 & 38.61 \\
\hline K_A-12 & 23.74 & 16.57 & 22.74 & 22.57 & 38.12 \\
\hline K_A-13 & 21.95 & 12.43 & 25.68 & 26.14 & 35.76 \\
\hline K_A-14 & 19.22 & 13.01 & 25.60 & 24.85 & 36.54 \\
\hline K_A-15 & 22.47 & 12.73 & 26.06 & 22.53 & 38.67 \\
\hline Min. & 14.05 & 11.89 & 21.92 & 22.53 & 32.94 \\
\hline Max. & 23.74 & 16.57 & 26.17 & 26.14 & 40.44 \\
\hline Average & 19.07 & 14.15 & 24.11 & 24.55 & 37.20 \\
\hline
\end{tabular}

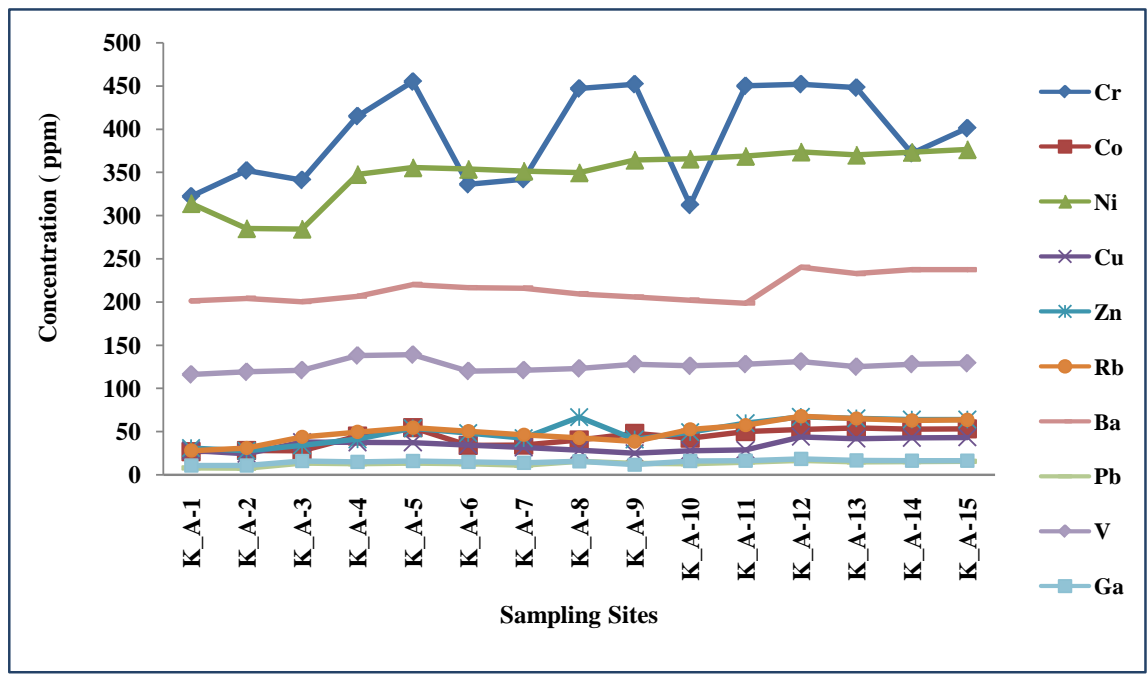

Figure 5. Heavy metal concentrations within the clay size sediments, Lesser Zab River.

heavy metals is listed in Table 4 and shown in Figures 6-8. The distribution of ( $\mathrm{Co}, \mathrm{Ni}, \mathrm{Ba}, \mathrm{Pb}, \mathrm{Rb}, \mathrm{Zn}$ and $\mathrm{Ga}$ ) and somewhat $(\mathrm{Cr}, \mathrm{V}$ and $\mathrm{Cu}$ ) shows significant positive correlation among themselves and major $\left(\mathrm{Al}_{2} \mathrm{O}_{3}, \mathrm{Fe}_{2} \mathrm{O}_{3}\right.$ and $\mathrm{MnO}$ ) 
Table 3. Elements Concentration of LZR Sediments

\begin{tabular}{|c|c|c|c|c|c|c|c|c|c|c|c|c|c|c|}
\hline Sample & $\mathrm{Al}_{2} \mathrm{O}_{3} \%$ & $\mathrm{MnO} \%$ & $\mathrm{Fe}_{2} \mathrm{O}_{3} \%$ & Cr ppm & Co ppm & Ni ppm & $\mathrm{Cu}$ ppm & Zn ppm & $\mathrm{Rb}$ ppm & Sr ppm & Ba ppm & $\mathrm{Pb}$ ppm & V ppm & Ga ppm \\
\hline K_A-1 & 6.737 & 0.0464 & 4.755 & 322 & 26.6 & 314 & 28.2 & 30.7 & 27.9 & 220.8 & 201.2 & 7.9 & 116 & 10.7 \\
\hline K_A-2 & 6.953 & 0.0648 & 4.765 & 352 & 28.1 & 285 & 24.3 & 27.7 & 30.9 & 222.8 & 204.2 & 7.5 & 119 & 10.8 \\
\hline K_A-3 & 9.317 & 0.0909 & 6.406 & 341 & 27.5 & 284.4 & 37.8 & 33.8 & 43.9 & 267.6 & 200.5 & 13.6 & 121 & 16 \\
\hline K_A-4 & 9.681 & 0.0987 & 6.315 & 415 & 44.7 & 347.6 & 37.5 & 41.1 & 49.5 & 301.2 & 206.6 & 12.6 & 138 & 14.9 \\
\hline K_A-5 & 10.317 & 0.1039 & 6.494 & 455 & 54.5 & 355.4 & 37.4 & 53.8 & 54.5 & 311.6 & 220.2 & 13.6 & 139 & 16 \\
\hline K_A-6 & 9.771 & 0.0987 & 6.298 & 336 & 33.9 & 353.6 & 34.3 & 48.1 & 50.5 & 303.2 & 216.6 & 12.6 & 120 & 14.9 \\
\hline K_A-7 & 10.525 & 0.0935 & 6.102 & 342 & 34.3 & 351.4 & 31.7 & 42.2 & 46.3 & 308.8 & 216 & 11 & 121 & 13.8 \\
\hline K_A-8 & 11.679 & 0.0883 & 5.606 & 447 & 40.1 & 349.6 & 28.6 & 66.7 & 42.7 & 306.4 & 209.4 & 15.6 & 123 & 15.7 \\
\hline K_A-9 & 11.533 & 0.0831 & 5.71 & 452 & 47.7 & 364.2 & 25 & 41 & 38.5 & 315.8 & 205.8 & 13.2 & 128 & 11.6 \\
\hline K_A-10 & 9.587 & 0.0779 & 5.514 & 312 & 42.3 & 365.4 & 27.9 & 49.3 & 52.6 & 315.6 & 202.2 & 12.6 & 126 & 15.9 \\
\hline K_A-11 & 9.041 & 0.0727 & 6.418 & 450 & 49.9 & 368.6 & 28.8 & 59.6 & 57.5 & 321.2 & 198.6 & 14.6 & 128 & 16.4 \\
\hline K_A-12 & 11.58 & 0.0962 & 7.416 & 452 & 52.3 & 373.6 & 43.9 & 67 & 67.8 & 321.5 & 240.2 & 16.6 & 131 & 18.5 \\
\hline K_A-13 & 11.61 & 0.088 & 7.387 & 448 & 54.1 & 370 & 41.9 & 65.4 & 65.1 & 321.8 & 232.8 & 14.9 & 125 & 16.6 \\
\hline K_A-14 & 10.6958 & 0.091 & 7.412 & 372 & 52.7 & 373.3 & 42.7 & 63.8 & 62.9 & 322.1 & 237.4 & 15.2 & 128 & 16.4 \\
\hline K_A-15 & 10.6962 & 0.094 & 7.415 & 401 & 53.2 & 376.3 & 43.2 & 64.01 & 63.5 & 322.4 & 237.4 & 15.5 & 129 & 16.4 \\
\hline Min. & 6.737 & 0.0464 & 4.755 & 312 & 26.6 & 284.4 & 24.3 & 27.7 & 27.9 & 220.8 & 198.6 & 7.5 & 116 & 10.7 \\
\hline Max. & 11.679 & 0.1039 & 7.416 & 455 & 54.5 & 376.3 & 43.9 & 67 & 67.8 & 322.4 & 240.2 & 16.6 & 139 & 18.5 \\
\hline Mean. & 9.9815 & 0.0859 & 6.2675 & 393.1333 & 42.7933 & 348.8267 & 34.2133 & 50.2807 & 50.2733 & 298.8533 & 215.2733 & 13.1333 & 126.1333 & 14.9733 \\
\hline S.D. & 1.5409 & 0.0151 & 0.8938 & 55.3055 & 10.3877 & 30.2726 & 6.8964 & 13.7699 & 12.1473 & 34.2233 & 14.9322 & 2.6486 & 6.5669 & 2.2855 \\
\hline C.V.(\%) & 15.437 & 17.589 & 14.261 & 14.068 & 24.274 & 8.678 & 20.157 & 27.386 & 24.163 & 11.452 & 6.936 & 20.167 & 5.206 & 15.264 \\
\hline
\end{tabular}

Table 4. Correlation coefficients for the selected variables; oxides, trace elements and sediments size fractions.

\begin{tabular}{|c|c|c|c|c|c|c|c|c|c|c|c|c|c|c|c|c|}
\hline & $\mathrm{Al}_{2} \mathrm{O}_{3}$ & $\mathrm{MnO}$ & $\mathrm{Fe}_{2} \mathrm{O}_{3}$ & $\mathrm{Cr}$ & Co & $\mathrm{Ni}$ & $\mathrm{Cu}$ & $\mathrm{Zn}$ & $\mathrm{Rb}$ & $\mathrm{Ba}$ & $\mathrm{Pb}$ & $\mathrm{V}$ & $\mathrm{Ga}$ & Clay & Silt & Sand \\
\hline & & & & & & & & & & & & & & Fraction & Fraction & Fraction \\
\hline $\mathrm{Al}_{2} \mathrm{O}_{3}$ & 1.00 & & & & & & & & & & & & & & & \\
\hline $\mathrm{MnO}$ & 0.727 & 1.00 & & & & & & & & & & & & & & \\
\hline $\mathrm{Fe}_{2} \mathrm{O}_{3}$ & 0.664 & 0.684 & 1.00 & & & & & & & & & & & & & \\
\hline $\mathrm{Cr}$ & 0.607 & 0.362 & 0.432 & 1.00 & & & & & & & & & & & & \\
\hline Co & 0.680 & 0.490 & 0.736 & 0.734 & 1.00 & & & & & & & & & & & \\
\hline $\mathrm{Ni}$ & 0.709 & 0.437 & 0.617 & 0.490 & 0.842 & 1.00 & & & & & & & & & & \\
\hline $\mathrm{Cu}$ & 0.471 & 0.626 & 0.908 & 0.240 & 0.542 & 0.384 & 1.00 & & & & & & & & & \\
\hline $\mathrm{Zn}$ & 0.737 & 0.467 & 0.735 & 0.593 & 0.797 & 0.800 & 0.563 & 1.00 & & & & & & & & \\
\hline $\mathrm{Rb}$ & 0.636 & 0.616 & 0.927 & 0.421 & 0.812 & 0.750 & 0.794 & 0.834 & 1.00 & & & & & & & \\
\hline $\mathrm{Ba}$ & 0.588 & 0.519 & 0.813 & 0.312 & 0.636 & 0.575 & 0.820 & 0.692 & 0.757 & 1.00 & & & & & & \\
\hline $\mathrm{Pb}$ & 0.835 & 0.654 & 0.810 & 0.622 & 0.753 & 0.685 & 0.629 & 0.874 & 0.818 & 0.572 & 1.00 & & & & & \\
\hline $\mathrm{V}$ & 0.440 & 0.602 & 0.495 & 0.632 & 0.766 & 0.520 & 0.437 & 0.405 & 0.543 & 0.309 & 0.515 & 1.00 & & & & \\
\hline $\mathrm{Ga}$ & 0.612 & 0.648 & 0.817 & 0.380 & 0.630 & 0.558 & 0.733 & 0.801 & 0.896 & 0.559 & 0.873 & 0.489 & 1.00 & & & \\
\hline Clay Fraction & 0.314 & 0.166 & 0.599 & 0.175 & 0.685 & 0.762 & 0.460 & 0.649 & 0.779 & 0.501 & 0.520 & 0.392 & 0.597 & 1.00 & & \\
\hline Silt Fraction & 0.562 & 0.213 & 0.060 & 0.310 & 0.259 & 0.522 & -0.117 & 0.336 & 0.084 & 0.016 & 0.385 & 0.205 & 0.122 & 0.102 & 1.00 & \\
\hline Sand Fraction & -0.614 & -0.257 & -0.360 & -0.340 & -0.564 & -0.815 & -0.145 & -0.607 & -0.473 & -0.273 & -0.580 & -0.369 & -0.409 & -0.602 & -0.856 & 1.00 \\
\hline
\end{tabular}



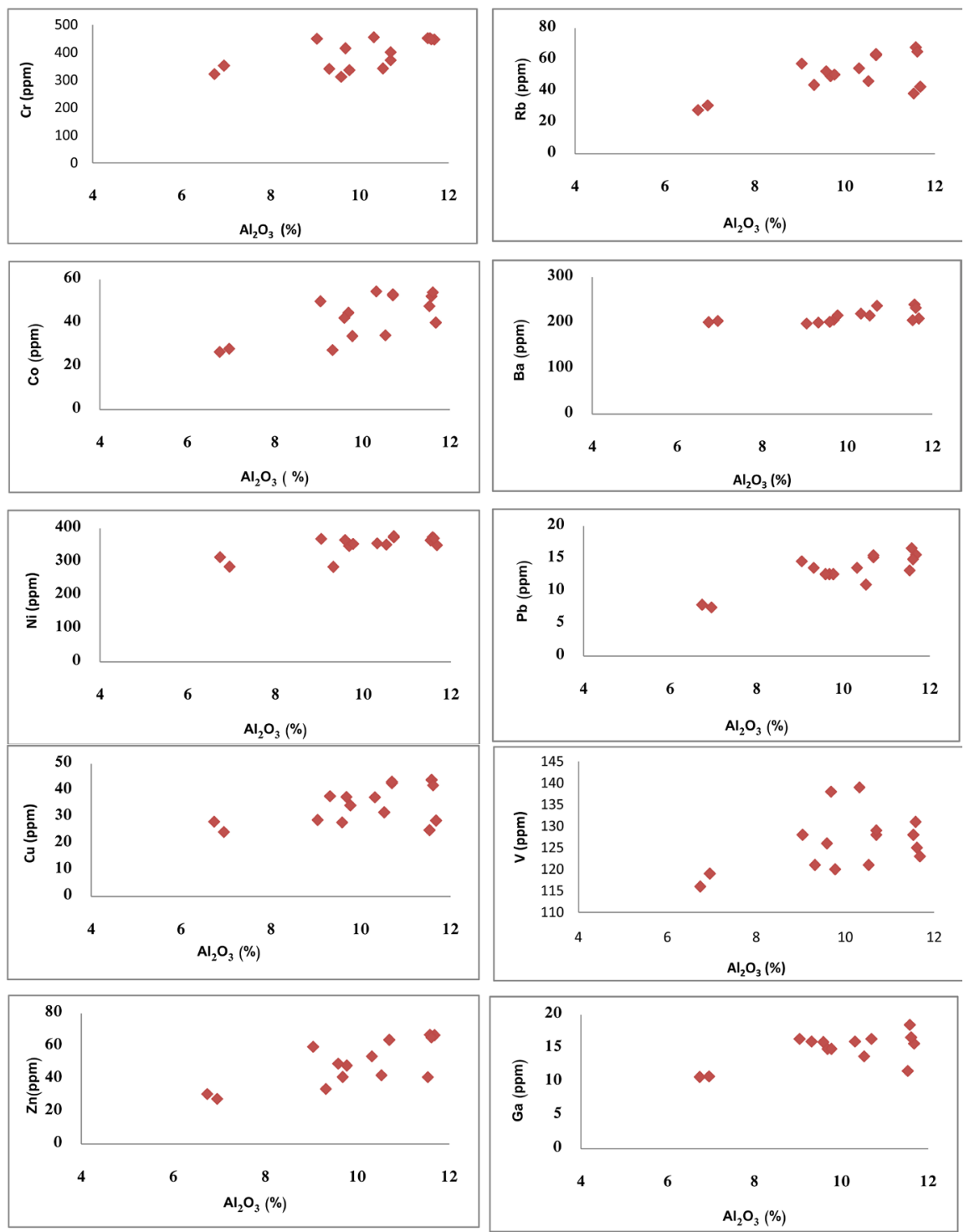

Figure 6. The relationship between $\mathrm{Al}_{2} \mathrm{O}_{3}$ and other elements in the studied samples.

oxides in the clay fraction, suggesting that a common mechanism regulates their abundance. Thus, suggest that these element concentrations are controlled mainly by Al-rich phases such as clay mineral abundances and $\mathrm{Fe}-\mathrm{Mg}, \mathrm{Fe}-\mathrm{Mn}$ oxides [18].

Moreover, $\mathrm{Co}, \mathrm{Ni}$ and $\mathrm{Cu}$ sourced from clay minerals while $\mathrm{Zn}$ could be sourced from the ferromagnesian heavy minerals such as amphiboles, pyroxenes etc. [30] as it is common with LZR and older sediments [18] [29]. [30] indicates that Co has moderate mobility controlled mainly by adsorption and co-precipitation with $\mathrm{Mn}-\mathrm{Fe}$ oxides. $\mathrm{Ba}$ and $\mathrm{Rb}$ are usually associated with feldspar and biotite [31] and clay minerals [18]. In addition, lead $(\mathrm{Pb})$ is generally adsorbed on iron oxide minerals while $\mathrm{Rb}$ with feldspar and mica [30]. Also, copper has intermediate mobility controlled by adsorption of $\mathrm{Fe}$ and Mn-oxides and organic matters; it is closely associated with geogenic (lithogenic) materials 

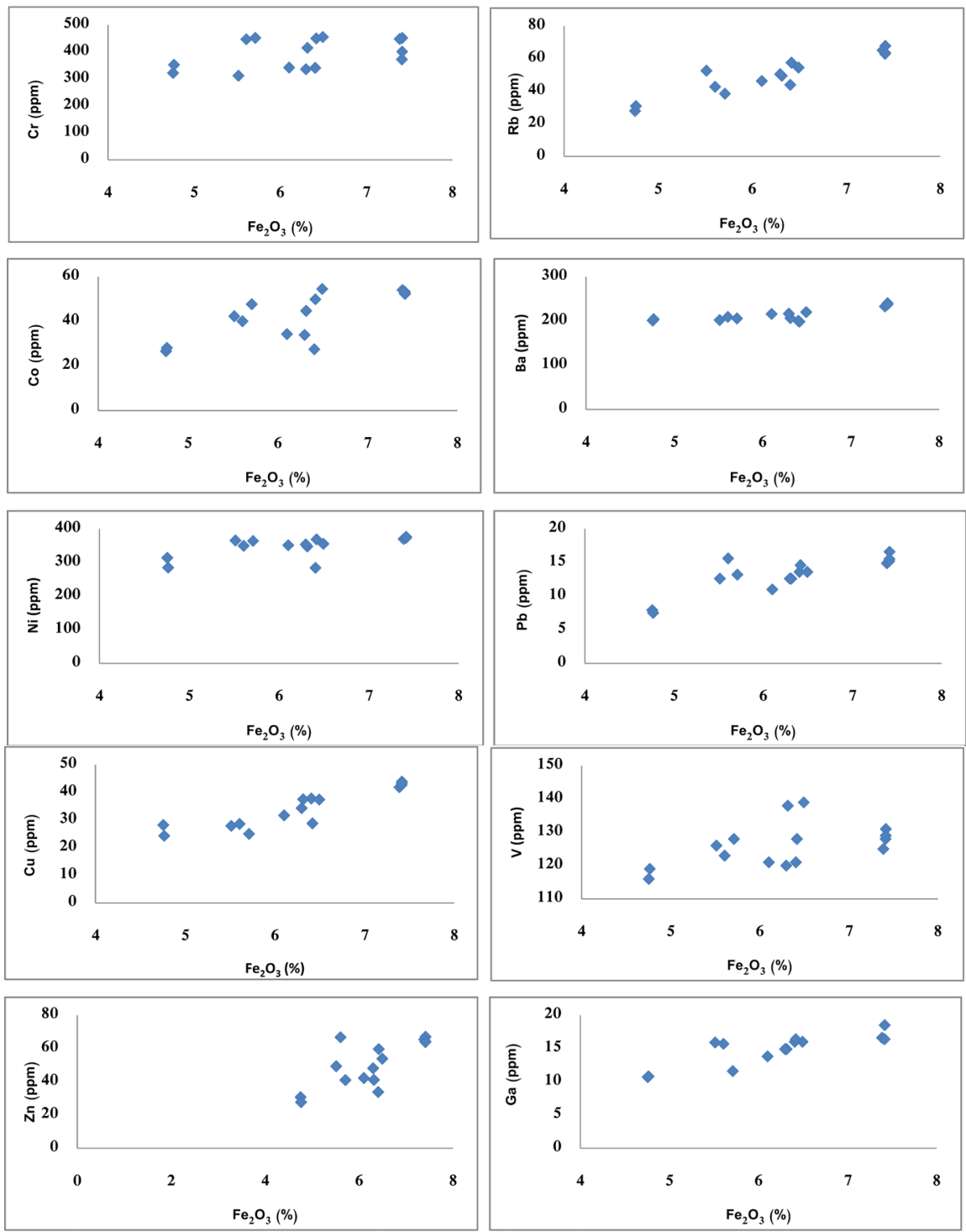

Figure 7. The relationship between $\mathrm{Fe}_{2} \mathrm{O}_{3}$ and other elements in the studied samples.

and exists in ultrabasic ophiolitic rocks [32]. Increasing heavy metal concentration in clay fraction of LZR sediments could be related to the adsorption on fine grain sediments. Thus, heavy metals portioning would essentially be influenced by clay content which in turn contributes significantly to the accumulation of heavy metals in the LZR sediments.

\subsection{Principal Component Analysis (PCA)-Factor Analysis}

PCA is used to determine the interaction between the measured independent properties. The principal component analysis has been widely applied in the interpretation of the geochemical and hydrogeochemical data [33] [34] [35]. It is one of the multivariate statistical analytical tools used to assess metal behavior in sediments and water [36]. Also, PCA is an approach to find the most crucial factors that describe the natural influence with eigenvalues $\geq 1.0$ [37]. According 

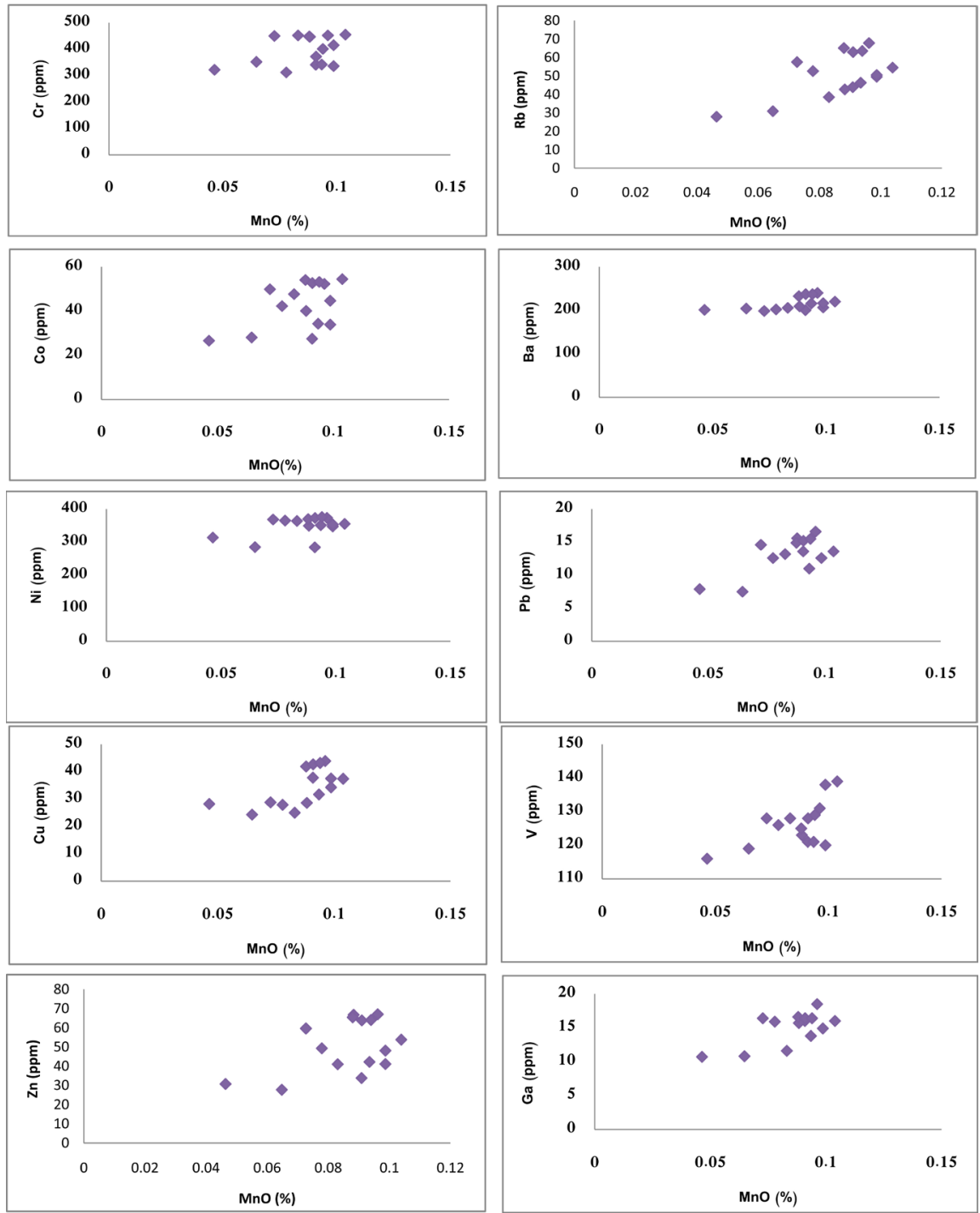

Figure 8. The relationship between $\mathrm{MnO}$ and other elements in the studied samples.

to [33] the factor loadings were classified as "excellent", "very good", "good" and "fair", as the absolute loading values of (>0.71), (0.71 - 0.63), (0.63 - 0.55) and $(0.55-0.45)$ respectively. For factor loadings, the loading was defined as excellent and very good and loadings of $(<0.63)$ were considered insignificant, and some of the factors not explained because contain loading fair lower than (0.55). Factor analysis allows us to group the elements with similar distribution.

In this study, three factors have been observed for LZR sediments, and components account for $(81.915 \%)$ of the total variation in the system, (the first component accounts for $60.119 \%$ of the variation, the second $13.616 \%$ and the third accounts for only 8.180\%) (Table 5, Figure 9). Thus, three components reflect the relation between the measured variables.

The first factor is explained $60.119 \%$ of the variation in the system and it is very important because influenced by $(\mathrm{Cu}, \mathrm{Co}, \mathrm{Zn}, \mathrm{Rb}, \mathrm{Ba}, \mathrm{Pb}, \mathrm{Ga})$ and clay fractions. This factor considered fine clay particles factor, which shows the fine 
Table 5. Characteristic Rotated (R-Mode) factor loading matrix for all (15) variables from the geochemical composition of LZR sediments.

\begin{tabular}{|c|c|c|c|c|}
\hline Variables & Factor 1 & Factor 2 & Factor 3 & Communalities \\
\hline $\mathrm{Al}_{2} \mathrm{O}_{3} \%$ & 0.546962 & 0.662129 & 0.453012 & 0.902141 \\
\hline $\mathrm{MnO} \%$ & 0.672562 & 0.242498 & -0.023412 & 0.751114 \\
\hline $\mathrm{Fe}_{2} \mathrm{O}_{3} \%$ & 0.943218 & 0.196815 & 0.078214 & 0.928397 \\
\hline $\mathrm{Cr}(\mathrm{ppm})$ & 0.366631 & 0.555019 & 0.313014 & 0.772464 \\
\hline Co (ppm) & 0.693371 & 0.57304 & 0.452112 & 0.809138 \\
\hline $\mathrm{Ni}(\mathrm{ppm})$ & 0.510450 & 0.757328 & 0.738215 & 0.925341 \\
\hline $\mathrm{Cu}(\mathrm{ppm})$ & 0.929565 & -0.07064 & -0.178521 & 0.879082 \\
\hline $\mathrm{Zn}(\mathrm{ppm})$ & 0.726315 & 0.560452 & 0.490012 & 0.842987 \\
\hline $\mathrm{Rb}(\mathrm{ppm})$ & 0.916444 & 0.307538 & 0.246522 & 0.968449 \\
\hline $\mathrm{Ba}(\mathrm{ppm})$ & 0.828031 & 0.11469 & 0.051124 & 0.828787 \\
\hline $\mathrm{Pb}(\mathrm{ppm})$ & 0.731829 & 0.550225 & 0.385123 & 0.898321 \\
\hline $\mathrm{V}(\mathrm{ppm})$ & 0.506821 & 0.415004 & 0.205231 & 0.759095 \\
\hline $\mathrm{Ga}(\mathrm{ppm})$ & 0.837013 & 0.273463 & 0.168022 & 0.785373 \\
\hline Clay \% & 0.777174 & 0.373859 & 0.506014 & 0.956534 \\
\hline Sand \% & -0.158531 & -0.91483 & -0.929221 & 0.943204 \\
\hline Silt \% & -0.178952 & 0.897248 & 0.830012 & 0.940370 \\
\hline$\%$ of Variance & 60.119 & 13.616 & 8.180 & 81915 \\
\hline Cumulative \% & 60.616 & 73.735 & 81.915 & \\
\hline
\end{tabular}

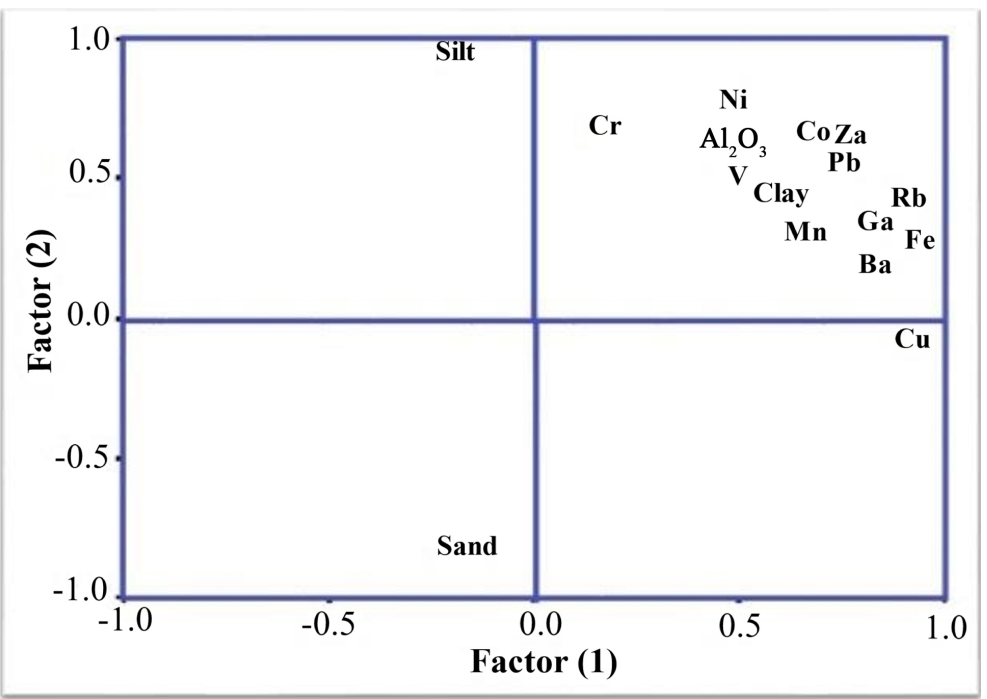

Figure 9. Principal component factor analysis loading two-dimension plots for sixteen variables.

grains influence on the enrichments of the heavy metals contents. Also, the existence of $\mathrm{Fe}_{2} \mathrm{O}, \mathrm{MnO}$ and $\mathrm{Al}_{2} \mathrm{O}_{3}$ in this factor indicated the influence of $\mathrm{Fe}-\mathrm{Mn}$ 
oxides-hydroxide phase and clay minerals to enrich the heavy metals contents within the LZR sediments. [18] illustrated that these element concentrations are controlled mainly by clay mineral abundances and Fe-Mg, Fe-Mn oxides. The second factor has $13.616 \%$ of total variance and affected by $(\mathrm{Cr}, \mathrm{Ni})$ and silt fractions. This factor considered independent fine minerals particles factor.

While $\mathrm{Ni}$ and $\mathrm{Cr}$ exist in the solid components of weathering productions [38], also substitution of Fe location by Ni in to the Fe-rich (goethite and hematite) minerals [38]. Also, the most abundant independent mineral is usually chromite which is resistant to the weathering, with heavy minerals (i.e. tourmaline, rutile, hornblende and magnetite) [39] [40] [41] which can exist in siliciclastic rocks in various grain sizes from sand to clay. Thus, $\mathrm{Cr}$ and $\mathrm{Ni}$ richness in the silt fraction of LZR sediments represented by the third factor.

\section{Conclusions}

Grain size distributions and textural composition indicate that these sediments are mainly characterized as clayey silt and silty sand as texture. This indicates that the fluctuation in the relative variation of the grain size distribution of the study sediments is because of the local contrast in the hydrological conditions such as stream speed, energy of transportation and geological, geomorphological and climatic natures that influenced these sediments properties.

The clay mineral assemblages in the LZR sediments consist mainly of palygorskite, kaolinite, illite, chlorite and smectite, following previous works, which reveals that these sediments were derived from rocks of similar mineralogical and chemical composition and that heavy metals portioning is linked to the tiny grain size amount.

The distribution of heavy metal shows significant positive correlation among themselves and major $\left(\mathrm{Al}_{2} \mathrm{O}_{3}, \mathrm{Fe}_{2} \mathrm{O}_{3}\right.$ and $\left.\mathrm{MnO}\right)$ oxides in the clay fraction, demonstrating a common mechanism regulates their abundance, thus, suggesting that these element concentrations are controlled mainly by Al-rich phases such as clay mineral abundances and $\mathrm{Fe}-\mathrm{Mg}$, Fe-Mn oxides.

\section{References}

[1] Joshua, E.O. and Oyebanjo, O.A. (2010) Grain-Size and Heavy Mineral Analysis of River Osun Sediments. Australian Journal of Basic and Applied Sciences, 4, 498-501.

[2] Jayalakshmi, K., Nair, K.M., Hisao, K. and Santosh, M. (2003) Mineralogical and Geochemical Variations as Indicators of Provenance in the Heavy Mineral Deposits of Ambalapuzha Beach Sands, SW Coast of India, Journal of Geosciences, 46, 157-168.

[3] Karbassi, A.R., Monavari, S.M., Nabi Bidhendi, G.R., Nouri, J. and Nematpour, K. (2008) Metal Pollution Assessment of Sediment and Water in the Shur River. Environmental Monitoring and Assessment, 147, 107-116. https://doi.org/10.1007/s10661-007-0102-8

[4] Murthy, B.N. (1977) Sedimentation Studies in Reservoirs, Technical Report, 1 (20), 
Central Board of Irrigation and Power, New Delhi, 105 p.

[5] Muwanga, A. (1997) Environmental Impacts of Copper Mining at Kilembe, Uganda: A Geochemical Investigation of Heavy Metal Pollution of Drainage Waters, Stream, Sediments and Soils in the Kilembe Valley in Relation to Mine Waste Disposal. Ph.D. Dissertation, Universitat Braunschweig, Germany.

[6] Zoumis, T., Schmidt, A., Grigorova, L. and Calmano, W. (2001) Contaminants in Sediments: Remobilisation and Demobilisation. Science of The Total Environment, 266, 195-202. https://doi.org/10.1016/S0048-9697(00)00740-3

[7] Chakravarty, M. and Patgiri, A.D. (2009) Metal Pollution Assessment in Sediments of the Dikrong River, N.E. India. Journal of Human Ecology, 27, 63-67. https://doi.org/10.1080/09709274.2009.11906193

[8] Salomons, W. and Forstner, U. (1984) Metals in the Hydrocycle. Springer-Verlag, Berlin, Heidelberg, New York, Tokyo. https://doi.org/10.1007/978-3-642-69325-0

[9] Prego, R., Barciela, C. and Varela, M. (1999) Nutrient Dynamics in the Galician Coastal Area (Northwestern Iberian Peninsula): Do the Rias Bajas Receive More Nutrient Salts than the Rias Altas? Continental Shelf Research, 19, 317-334. https://doi.org/10.1016/S0278-4343(98)00099-5

[10] Rasul, A.K. (2013) Hydrochemistry and Geochemistry of Recent Sediments of Lesser Zab River and Dokan Reservoir, Kurdistan Region-NE Iraq. Ph.D Thesis, College of Science, University of Salahaddin-Erbil, $163 \mathrm{p}$.

[11] Juracic, M., Bauman, I. and Pavdic, V. (1982) Are the Sediments the Ultimate Depository of Hydrocarbon Pollutions? Vème Journées Etudes Pollutions Marin, Cannes, 83-87.

[12] Ho, H.H., Swennen, R. and Van Damme, A. (2010) Distribution of Heavy Metals in Estuarine Sediments near Cua Ong Harbor, Ha Long Bay, Vietnam. Geologica Beligica, 13, 37-47.

[13] Bolton, C.M.G. (1958) The Geology of Ranyia Area. GEOSURV, Int. Report No. 276. Site Investigation Company Ltd., England.

[14] Jassim S.Z. and Goff J.C. (2006) Geology of Iraq, Dolin, Prague, Czech Republic. $241 \mathrm{p}$.

[15] Jassim, S.Z., Raiswell, R., Bottrell, H. (1999) Genesis of the Middle Miocene Strata-Bound Sulphur Deposits of Northern Iraq. Journal of the Geological Society London, 156, 25-99. https://doi.org/10.1144/gsigs.156.1.0025

[16] Numan, N.M.S. (1997) A Plate Tectonic Scenario for the Phanerozoic Succession in Iraq. Journal of the Geological Society of Iraq, 30, 85-110.

[17] Numan, N.M.S. (2001) Discussion on; Dextral Transportation in Late Cretaceous Continental Collision, Sanandaj-Sirjan-Zone, Western Iran. Journal of Structural Geology, 23, 2033-2034. https://doi.org/10.1016/S0191-8141(01)00075-X

[18] Ali, A.R. (2012) Major and Trace Elements Distribution in Stream Sediments of the Lesser Zab River at Northeastern Iraq: Implications to Weathering and Transportation. Iraqi Bulletin of Geology and Mining, 8, 25-44.

[19] Timothy, E. and Tour, La. (1989) Analysis of Rocks Using X-Ray Fluorescence Spectrometry. The Rigaku Journal, 6, 3-9.

[20] Johnson, D.M., Hooper P.R. and Conrey, R.M. (1997) XRF Analysis of Rocks and Minerals for Major and Trace Elements on a Single Low Dilution Li-Tetraborate Fused Bead. Advances in X-Ray Analysis, 41, 843-867.

[21] Stephens, W.E. and Calder, A. (2004) Analysis of Non-Organic Elements in Plant 
Foliage Using Polarized X-Ray Fluorescence Spectrometry. Analytica Chimica Acta, 527, 89-96. https://doi.org/10.1016/j.aca.2004.08.015

[22] Carver, R.E. (1971) Procedures in Sedimentary Petrology. John Wiley and Sons, New York, 329 p.

[23] Folk, R.L. (1974) Petrology of Sedimentary Rocks. Hemphill, TX, 182 p.

[24] Folk, R.L. and Ward, W.C. (1957) Brazos River Bar-A Study in the Significance of Grain Size Parameters. Journal of Sedimentary Petrology, 27, 3-26. https://doi.org/10.1306/74D70646-2B21-11D7-8648000102C1865D

[25] Carroll, D. (1970) Clay Minerals: A Guide to Their X-Ray Identification. Special Paper 126. Geological Society of America, Colorado, 80 p. https://doi.org/10.1130/SPE126-p1

[26] Chao, G.Y. (1969) $2 \theta(\mathrm{Cu})$ Table for Common Minerals. Geological Paper 69-2, Ottawa, Canada, $34 \mathrm{p}$.

[27] Picard, M.D. (1971) Classification of Fine-Grained Sedimentary Rocks. Journal of Sedimentary Petrology, 41, 179-195.

[28] Ali, A.R. and Al-Dabagh, S.M (2007) Mineralogy of Recent Sediments and It's Relation with Outcrop Rocks in Al-Adhaim River Basin-Eastern Iraq. Kirkuk University Journal Scientific Studies, 2, 60-77.

[29] Al-Juboury, A. I. (2009) Natural Pollution by Some Heavy Metals in the Tigris River, Northern Iraq. International Journal of Environmental Research, 3, 189-198.

[30] Goldschmidt, V.M. (1964) Geochemistry, Oxford. Clarendon Press, Wotton-under-Edge, $730 \mathrm{p}$.

[31] Mason, B. (1966) Principles of Geochemistry. 3rd Edition, John Wiley \& Sons Inc, New York, 329 p.

[32] Hejabi, A.T., Basavarajappa, H.T. and Qaid Saeed, A.M. (2010) Heavy Metal Pollution in Kabini River Sediments. International Journal of Environmental Research, 4, 629-636.

[33] Evans, C.D., Davies, T.D., Wigington Jr, P.J., Tranter, M. and Kretser, W.A. (1996) Use of Factor Analysis to Investigate Processes Controlling the Chemical Composition of Four Streams in Adirondack Mountains, New York. Journal of Hydrology, 185, 297-316. https://doi.org/10.1016/0022-1694(95)02997-4

[34] Cameron, E.M. (1996) Hydrogeochemistry of the Fraser River, British Columbia: Seasonal Variation in Major and Minor Components. Journal of Hydrology, 182, 209-225. https://doi.org/10.1016/0022-1694(95)02924-9

[35] Adams, S., Titus, R., Pietersen, K. and Harris, G. (2001) Hydrochemical Characteristics of Aquifers near Sutherland in the Western Karoo, South Africa. Journal of Hydrology, 241, 91-103. https://doi.org/10.1016/S0022-1694(00)00370-X

[36] Zhou, H.Y., Peng, X.T. and Pan, J.M. (2004) Distribution, Source and Enrichment of Some Chemical Elements in Sediments of the Pearl River Estuary, China. Continental Shelf Research, 24, 1857-1875. https://doi.org/10.1016/j.csr.2004.06.012

[37] Kim, J.-O. and Mueller, C.W. (1978) Factor Analysis: Statistical Methods and Practical Issues. HA29.Q35/VOL 14, Sage Publications, Beverly Hills, CA. https://doi.org/10.4135/9781412984256

[38] Krauskopf, K.B. (1979) Introduction to Geochemistry. 2nd Edition, McGraw Hill, New York, 617 p.

[39] Ali, A.R. (1996) Mineralogy and Geochemistry of Stream Sediments, Adhaim River Basin, Eastern Iraq. Unpublished M.Sc. Thesis, Mosul University, Iraq, 99 p. 
[40] Bhattacharjee, J., Ghosh, K.K. and Bhattacharya, B. (2017) Petrography and Geochemistry of Sandstone-Mudstone from Barakar Formation (Early Permian) Raniganj Basin, India: Implications for Provenance, Weathering and Marine Depositional Conditions during Lower Gondwana Sedimentation. Geological Journal, 1-12. https://doi.org/10.1002/gj.2946

[41] Hossain, H.Z., Kawahata, H., Roser, B.P., Sampei, Y., Manaka, T. and Otani, S. (2017) Geochemical Characteristics of Modern River Sediments in Myanmar and Thailand: Implications for Provenance and Weathering. Chemie der Erde-Geochemistry, 77, 443-458. https://doi.org/10.1016/j.chemer.2017.07.005 